ISSN 1112-9867

\title{
SEISMIC PERFORMANCE ON STIFFNESS AND HYSTERESIS LOOP OF INTERIOR WALL-SLAB JOINT FOR TUNNEL FORM BUILDING DESIGNS TO BRITISH STANDARD
}

\author{
M. A. Masrom ${ }^{1, *}$, H. M. Yee ${ }^{1}$, M. E. Mohamed ${ }^{2}$ and N. H. A. Hamid ${ }^{2}$ \\ ${ }^{1}$ Faculty of Civil Engineering, UniversitiTeknologi MARA, 13500 PermatangPauh, Penang, \\ Malaysia \\ ${ }^{2}$ Faculty of Civil Engineering, UniversitiTeknologi MARA, 40450 Shah Alam, Selangor, \\ Malaysia
}

Published online: 17 October 2017

\begin{abstract}
Wall-slab is a system suitable for use in the field of high-rise building where the main load resisting system is in the form rigidly connected wall-slab member. This paper presents the performance of a full-scale wall-slab joint in tunnel form system subjected to lateral cyclic loading. The objectives are to determine seismic behavior on the hysteresis loops and stiffness. Interior wall-slab joint was tested up to failure drift of $1.5 \%$. The biggest hysteresis loops were occurred at the closest to the double actuator. The stiffness of wall-slab joint started to decrease from $0.25 \%$ drift until $0.5 \%$ drift and lost it stiffness after $0.5 \%$ drift. Incretion of the percentage of reinforcement bars in the wall-slab and proper detailing at joint is required for seismic loading.
\end{abstract}

Keywords: wall-slab; hysteresis; stiffness; joint; cyclic.

Author Correspondence, e-mail: ashaarimasrom@ppinang.uitm.edu.my doi: http://dx.doi.org/10.4314/jfas.v9i5s.7 


\section{INTRODUCTION}

One of the major issues addresses in designing of high-rise reinforced concrete (RC) building is to determine the capacity of RC structures subjected to lateral force consists of wind and earthquake loads. However, wind load is not a major problem in Malaysia because wind load is too small as compare to earthquake load. Many codes of practice were developed to accommodate wind load factor in determining structural integrity and stability of the RC buildings. Meanwhile, seismic load is always impair to the building structure and cause the holocaust to buildings either partial or full collapse. A lot of past earthquakes events in Sumatra caused tremor to the people who live in high-rise RC buildings in Malaysia. It was reported that many Malaysian, especially those who stay in high-rise buildings felt the swaying of the buildings during these earthquakes. It was discovered that through building inspections, there were about $30 \%$ out of 65 buildings in Kuala Lumpur, Putrajaya and Klang are very vulnerable to earthquake. The main reason is that these RC buildings were designed in accordance to British Standard (BS 8110) where there is no provision for earthquake loading.

The initial work and analysis of tunnel form building was conducted by [1]. Followed by [2] who were carried out experiment work using tunnel form building by testing its under quasi-static cyclic lateral loadings. They discovered the wall-slab interface suffered severe damages after the testing. In the RC building, the crucial zone in determining the stability of the building is the seismic performance of joint in beam-column, wall-foundation, wall-slab and slab-beam [3]. The reinforced concrete joints should have sufficient strength to resist the induced stresses and sufficient stiffness to control undue deformations. Large deformations of joints result in significant increase in the inter-storey displacement. Basics seismic design requirements for RC buildings are to avoid any collapse of the structures under strong earthquake and remain functional under low earthquake excitations [4]. There are three basic minimum parameters need to be fulfilled in seismic design of RC buildings in medium and high seismic regions. The first parameter is the ductility of structures starting from elastic to inelastic behavior which can be measured in term of displacement, strains and curvature. The amount of reinforcement bars in concrete is very important in determining the ductility of 
structures [5].

The second parameter is the stiffness of the structure which can be classified as brittle or flexible [6]. Brittle structure having greater stiffness proves to be less durable during earthquake while ductile structure performs well in earthquake. The brittle members need strong enough to withstand the lateral force. This force induces by yielding of the ductile members, allowing a suitable margin to give a high level of confidence that the brittle elements will not reach their failure loads [7].

Predominantly, RC buildings in Malaysia were designed without considering the seismic loading in RC buildings. Members in the structure should have adequate strength to carry the design loads safely. It should be pointed out that the designer should avoid brittle type of failure by making a capacity design [7]. The third parameter is the capability of the structures to absorb earthquake energy during ground motion. The construction materials such as concrete, steel and timber are capable to absorb earthquake energy up to 5\% only [8]. However, structures with base isolation system or active/passive damper can absorb the energy up to $20 \%$ [9]. In [10] shows a computational analysis of seismic damage in shear wall-slab junction of an RC wall-frame building. Bending capacity for support stiffness in wall-slab system have been studied by [11-15]. Most of civil engineers assume that earthquakes will not happen in Malaysia as compare with Indonesia which located closed to the Pacific Ring of Fire. However, they cannot overlook this matter because Kuala Lumpur is located $450 \mathrm{~km}$ away from Sunda Plate. This plate is one of the most active plates in the world with velocity movement of $70 \mathrm{~mm} /$ year. Furthermore, there are a few sleeping fault lines in West Malaysia such as Kuala Lumpur Fault, Bukit Tinggi Fault and Kenyir Fault which cause very small magnitude of earthquake between 2.8 to 4.2 scale Richter. Therefore, the buildings in Malaysia are susceptible to damage and risk of collapse if bigger earthquake happened in the neighboring countries or in Malaysia. Due to that situation, the aim of this research is to perform interior wall-slab joint designed according to BS 8110 and tested under earthquake loading. It is important to conduct an experiment work in order to give the real scenario of the overall behavior of RC buildings during minor and major earthquake. 


\section{DESIGN OF WALL-SLAB CONNECTION}

The specimen comprises of reinforced foundation beam, wall and slab as shown in Fig. 1. The length of foundation is $1800 \mathrm{~mm}, 900 \mathrm{~mm}$ width and $400 \mathrm{~mm}$ height. Meanwhile, the height, width and thickness of wall panel which is seating on foundation beam are $1500 \mathrm{~mm}, 1000 \mathrm{~mm}$ and $150 \mathrm{~mm}$ respectively. The width, thickness and length of the floor slab are $1500 \mathrm{~mm}$, $150 \mathrm{~mm}$ and $1500 \mathrm{~mm}$ respectively. The diameter of longitudinal reinforcement bars for the foundation beam are $16 \mathrm{~mm}$ and diameter of transverse reinforcement bars are $12 \mathrm{~mm}$. The fabric wires mesh (BRC-7) is with dimension of $200 \mathrm{~mm}$ vertically and $100 \mathrm{~mm}$ horizontally were used in wall and slab as double layer of wires mesh. The lapping bars from foundation beam and wall are designed as fixed joint and comprises of fixed moment and shear force.

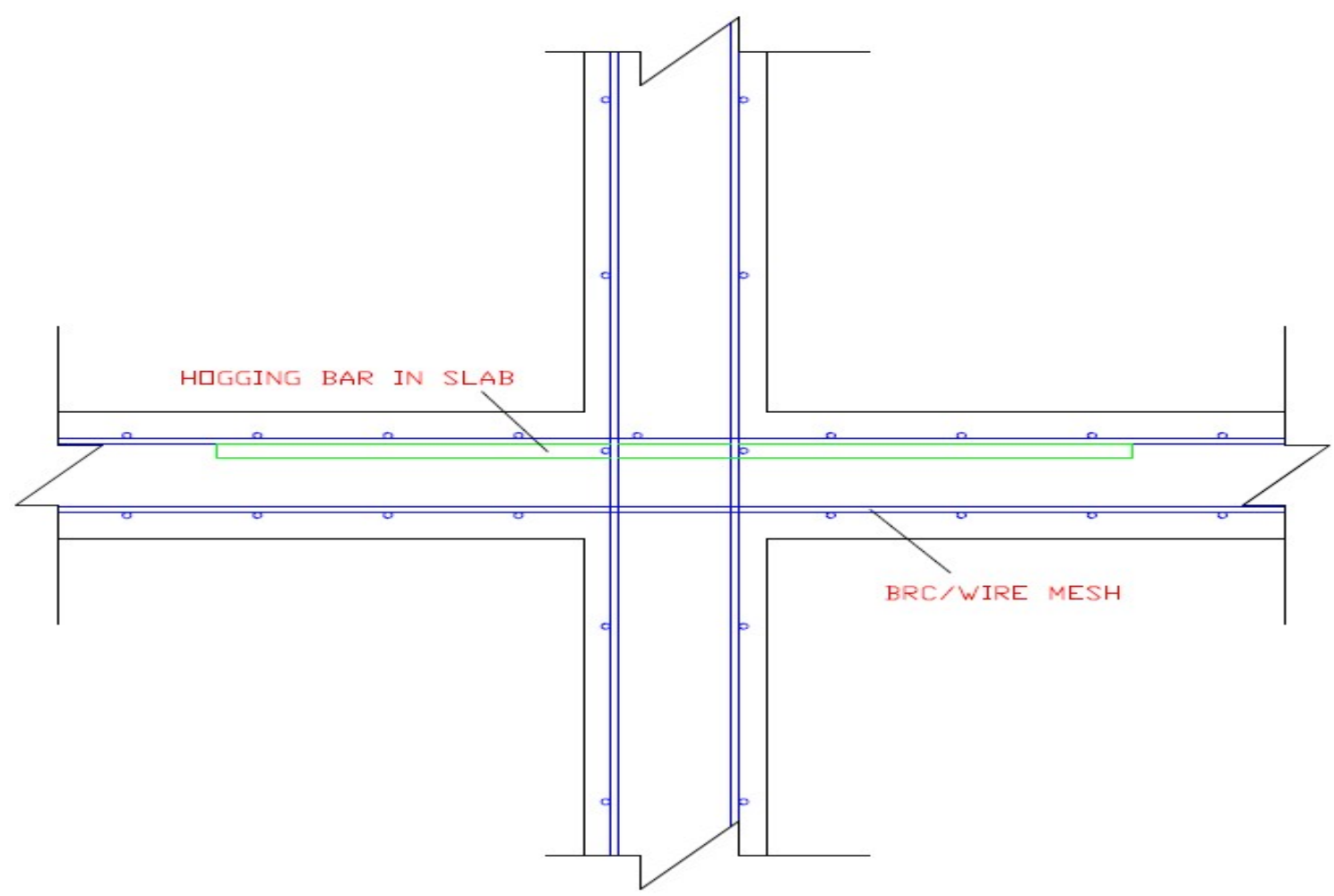

Fig.1.Basic wall-slab specimen design

\section{CONSTRUCTION AND EXPERIMENTAL WALL-SLAB SPECIMEN SET-UP}

The sub-assemblage of RC wall-slab joint comprises of foundation shear wall and floor slab were constructed on strong floor of Faculty of Civil Engineering, UniversitiTeknologi MARA, Malaysia. Initially, the foundation beam's cage was prepared in the lab prior to the construction of formwork as shown in Fig. 2. Fabric wires mesh (BRC-7) were cut according 
to the size of the floor slab and wall panel. Reinforcement bars with $12 \mathrm{~mm}$ diameter were used to tie wall and slab skeleton at cross-bracing joints with $200 \mathrm{~mm}$ spacing between each other.

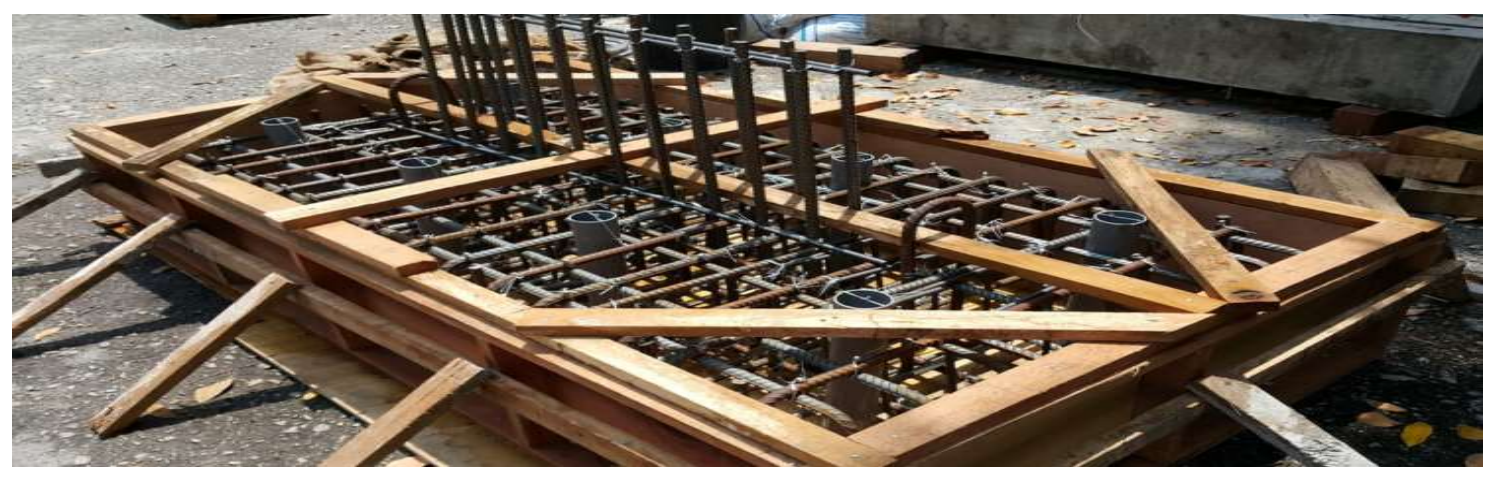

Fig.2.Preparation of foundation beam cage

The wet concrete was poured up to the level of slab steel mold and let the wet concrete to cure and hardened for a few days. The sub-assemblage of wall-slab joint was painted with color before any experimental work took place. This specimen a shown in Fig.3 is ready for instrumentation and experimental set-up before start testing.

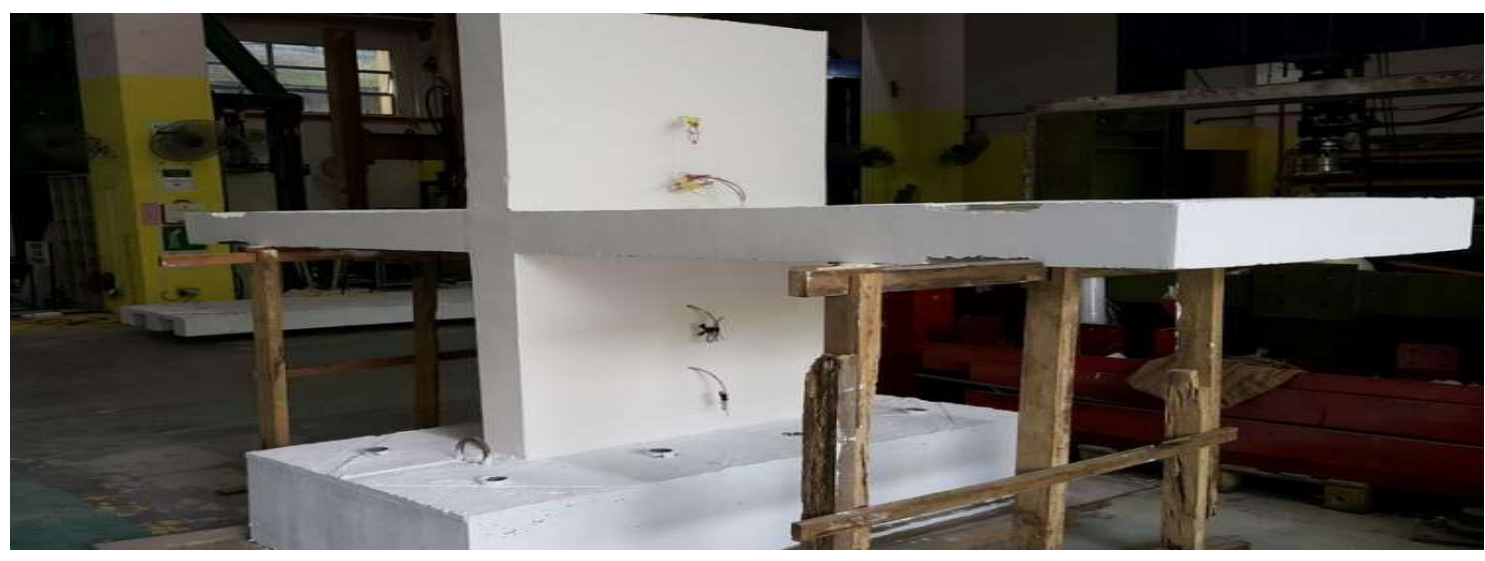

Fig.3. The wall-slab specimen is ready for testing

Fig. 4 shows the systematic arrangement of linear potentiometers and location of double actuator. Load cell with capacity of $250 \mathrm{kN}$ is connected to double actuator and supported by the reaction frame. A total number of 10 LVDT were installed to record the deflection of sample. Strain gauges were installed to record the strain of bars due to alternate tension and compression stress. Strain gauges can detect the elongation of reinforcement bar starting from yielding, elasto-plastic, plastic and ultimate strain. The strain gauges at reinforcement bar 
were installed prior to casting of sample. The exact and detail arrangement of strain gauges attached to the reinforcement bars (BRC-A7) are shown in Fig. 5.

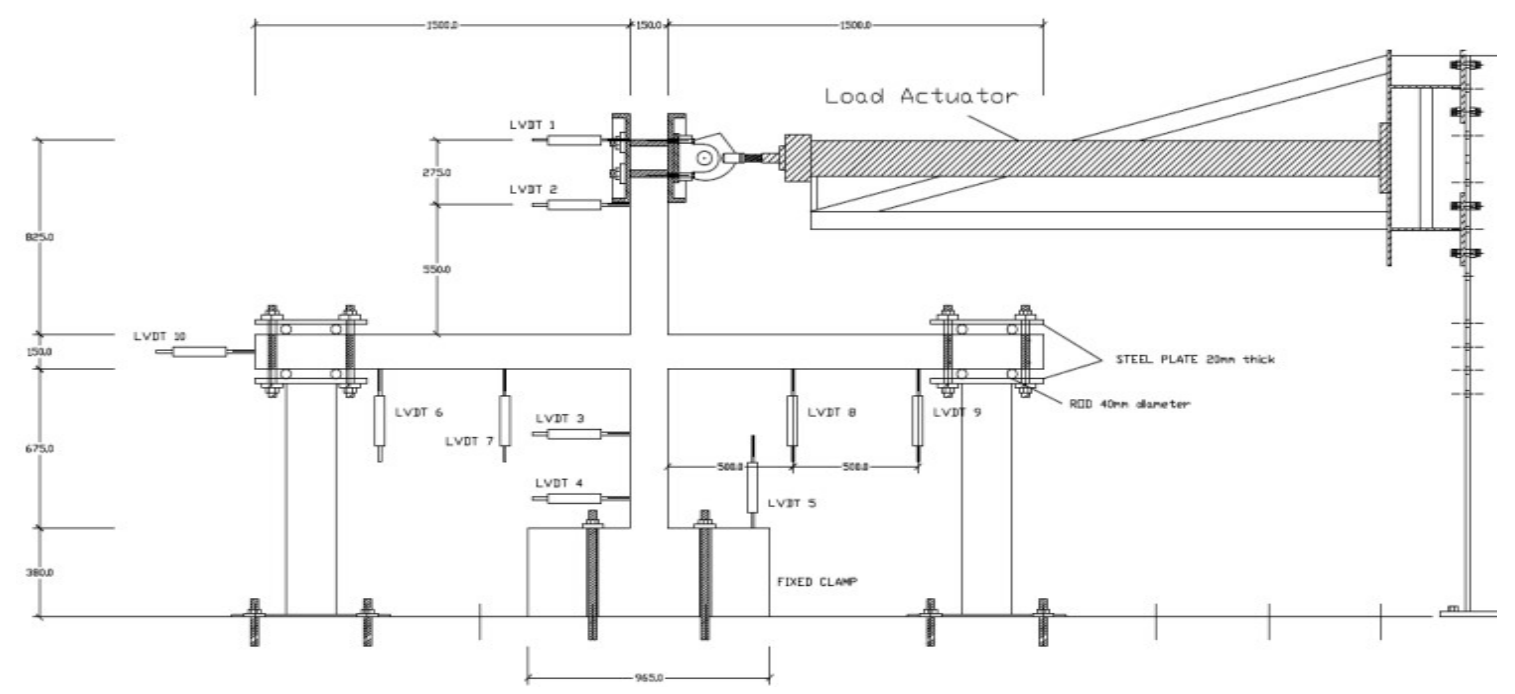

Fig.4. Sample of wall-slab connection together with positions of LVDT's

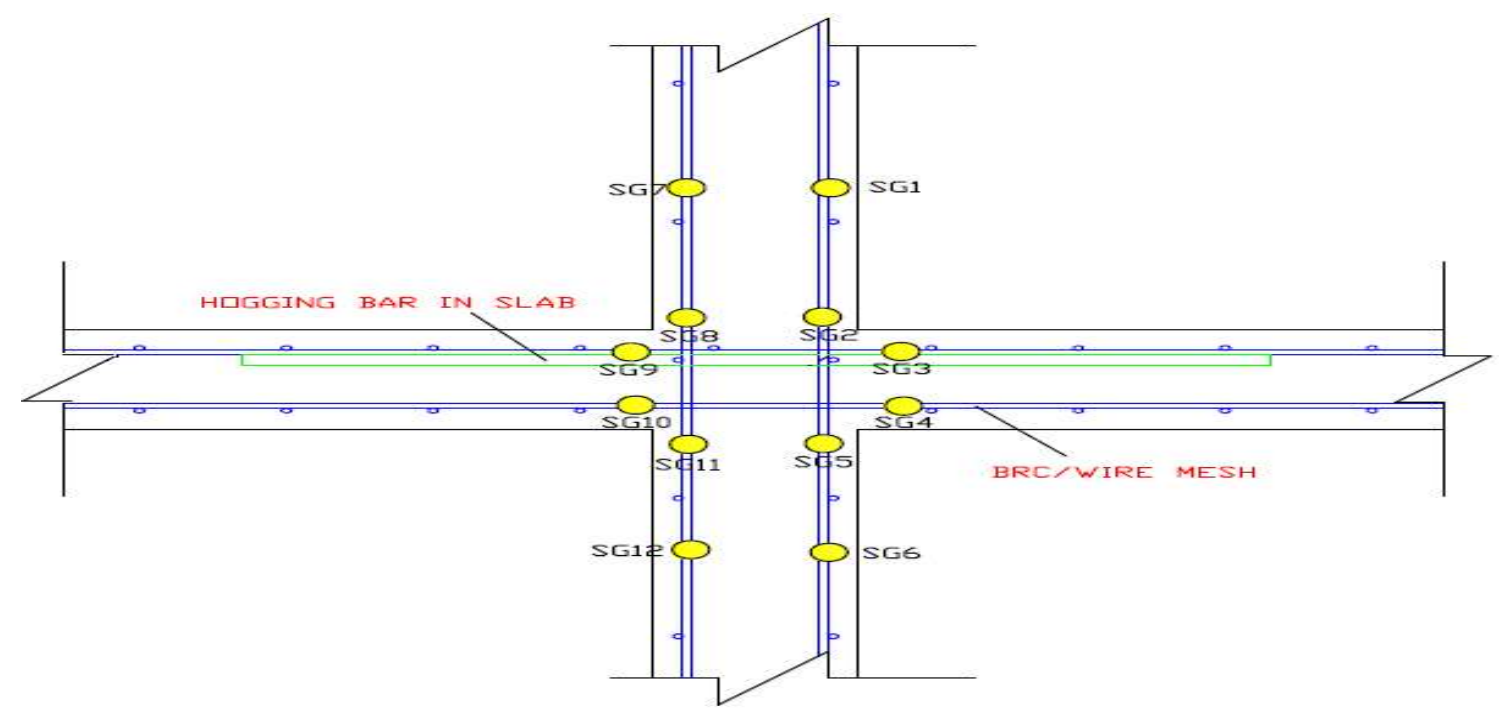

Fig.5. Location of strain-gauge on the BRC-A7

Double actuator imposed the lateral cyclic loading on to the wall using control displacement. While the head of load cell is connected to steel plate and clamped to the wall by screwed up snug tight the treaded bars. The RC wall became sandwiched by steel plate clamping to the double actuator head so that the wall can be pushed and pulled laterally during the experiment work without any gap between the steel plates. At end of the floor slab, two steel plates are attached to slab using high yield threaded rods. Two numbers of rods were located between 
the slab and steel plates to allow the slab roll on the support during the testing. The foundation beam is clamped to strong floor by penetrating the high yield threaded bar through the holes located in foundation beam.

\section{RESULTS AND DISCUSSION}

The hysteresis loops of wall-slab joint have plotted by using the data obtained from $0.1 \%$ drift until 1.5\% drift as shown in Fig. 7. It shows the hysteresis loop of wall-slab joint which based on data obtained in LVDT 1. By observing the individual hysteresis loop at every drift percentage, it can be discovered that the individual loop shows the small enclosed pattern of loop. This indicate the small energy dissipation in the system which not effective to maintain longer under lateral cyclic loading. Consequently, the brittle failure happened in the wall-slab connection.

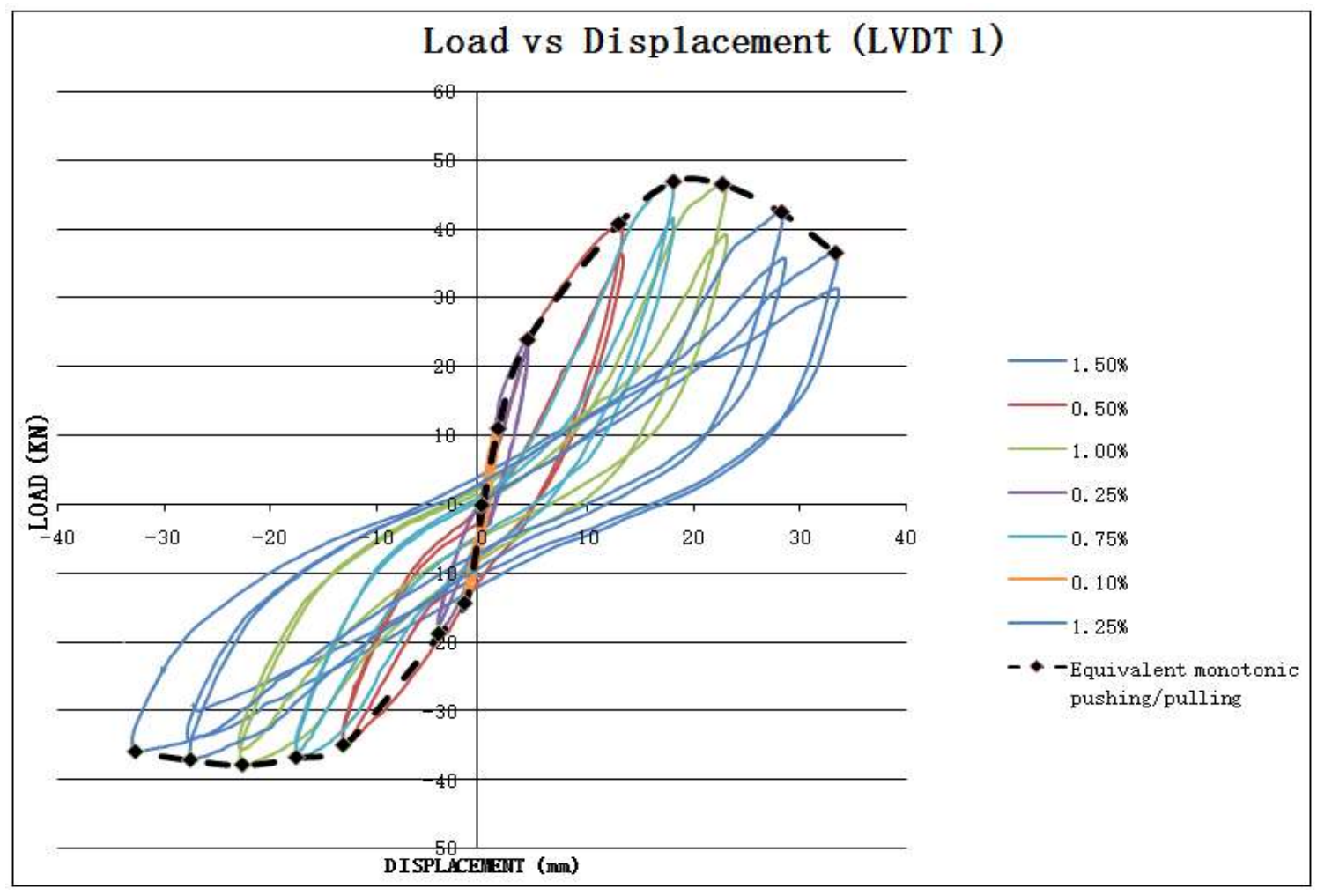

Fig.7. Hysteresis loops of wall based on LVDT 1

Fig. 8 shows the stiffness profile of the wall-slab joint for LVDT 1. There are two line profiles in blue and orange colors which represent pulling stiffness and pushing stiffness respectively. At $0.1 \%$ drift pulling stiffness of the wall is greater than its pushing stiffness. The position 
was return back as had occurred at $0.75 \%$ pushing stiffness of the wall is greater than its pulling stiffness. By focusing on pushing stiffness of the wall, it can be observed that the drop constantly in stiffness was take place at $0.5 \%$ drift.

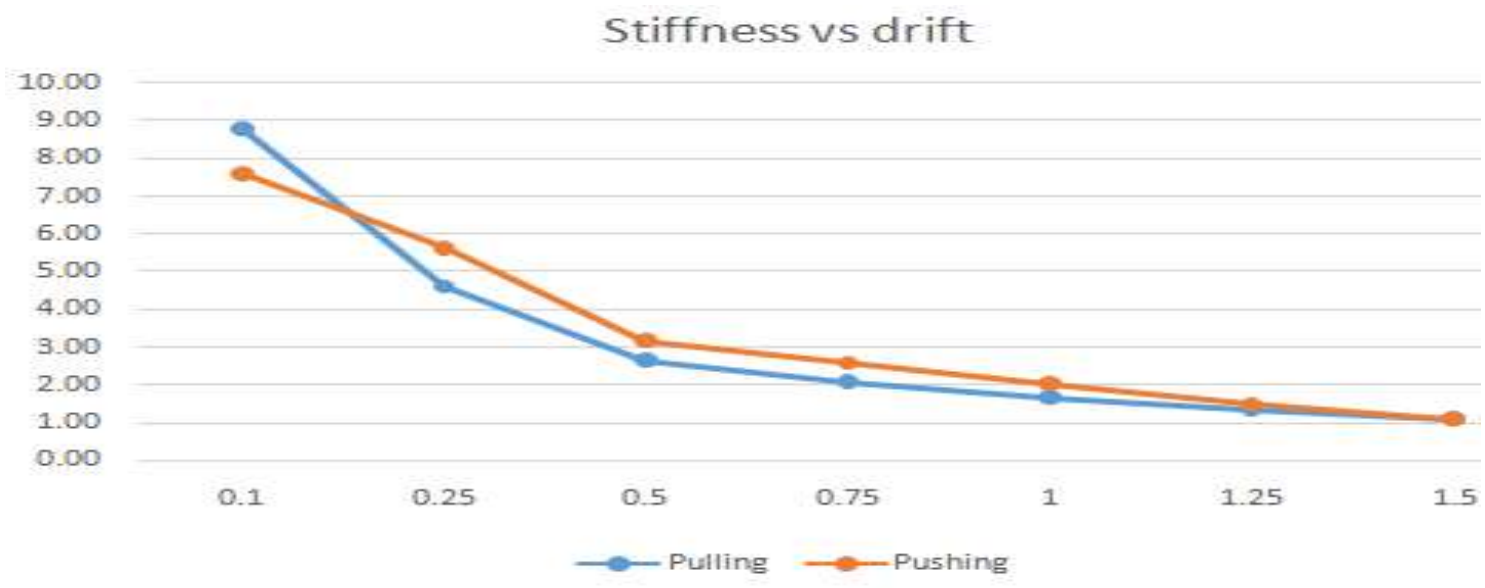

Fig.8. Stiffness profile of wall based on LVDT 1

Fig. 9 shows the stiffness profile of the wall-slab joint for LVDT 2. At 0.1\% drift pushing stiffness of the wall is greater than its pulling stiffness. The position was return back as had occurred at $0.1 \%$ drift previously at $0.5 \%$ drift intensity. By focusing on pushing stiffness of the wall, it can be observed that the drop constantly in stiffness was take place at $0.75 \%$ drift. Basically, the stiffness of wall in both load direction are showing degradation in stiffness with respect to an ascending in drift intensity.

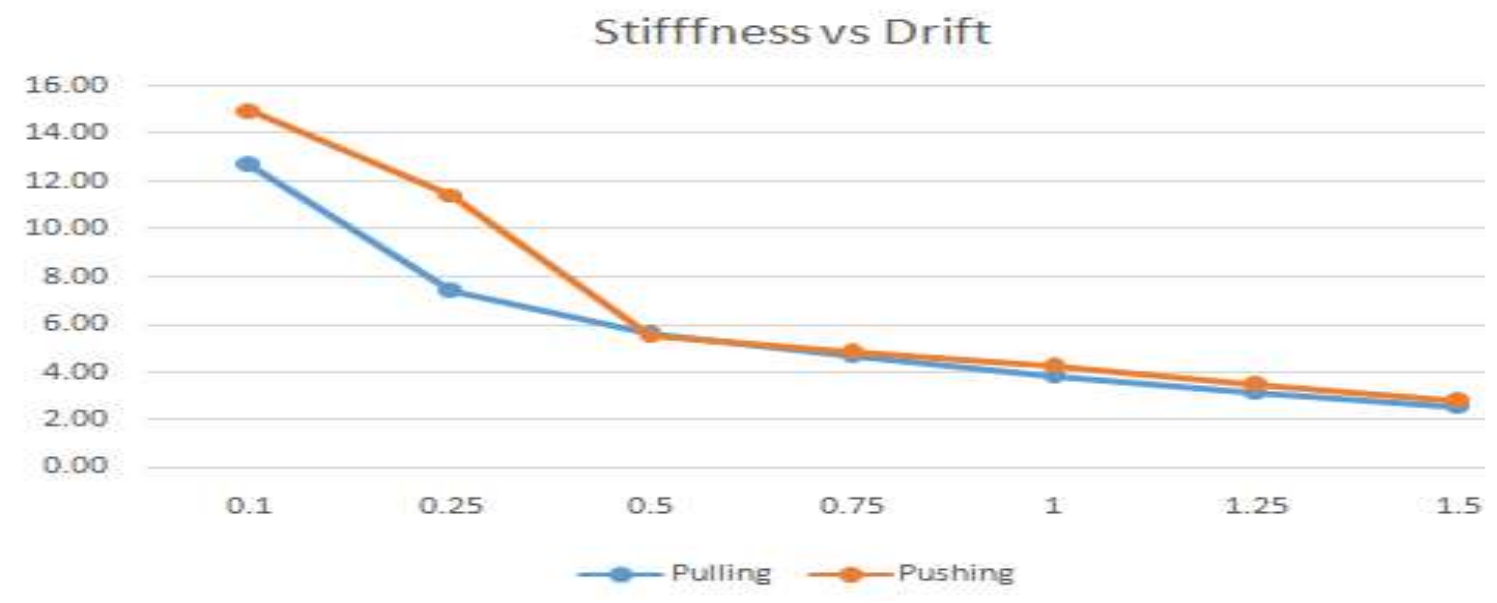

Fig.9. Stiffness profile of wall based on LVDT 2

Fig. 10 shows the stiffness profile of the wall-slab joint for LVDT 3. At $0.1 \%$ drift pushing 
stiffness of the wall is greater than its pulling stiffness. The position was return back as had occurred at $0.1 \%$ drift previously within $0.5 \%$ to $1.25 \%$ drift intensity. By focusing on pushing stiffness of the wall, it can be observed that the sudden drop in stiffness was take place at $0.5 \%$ drift. Basically, the stiffness of wall in both load direction are showing degradation in stiffness with respect to an ascending in drift intensity.

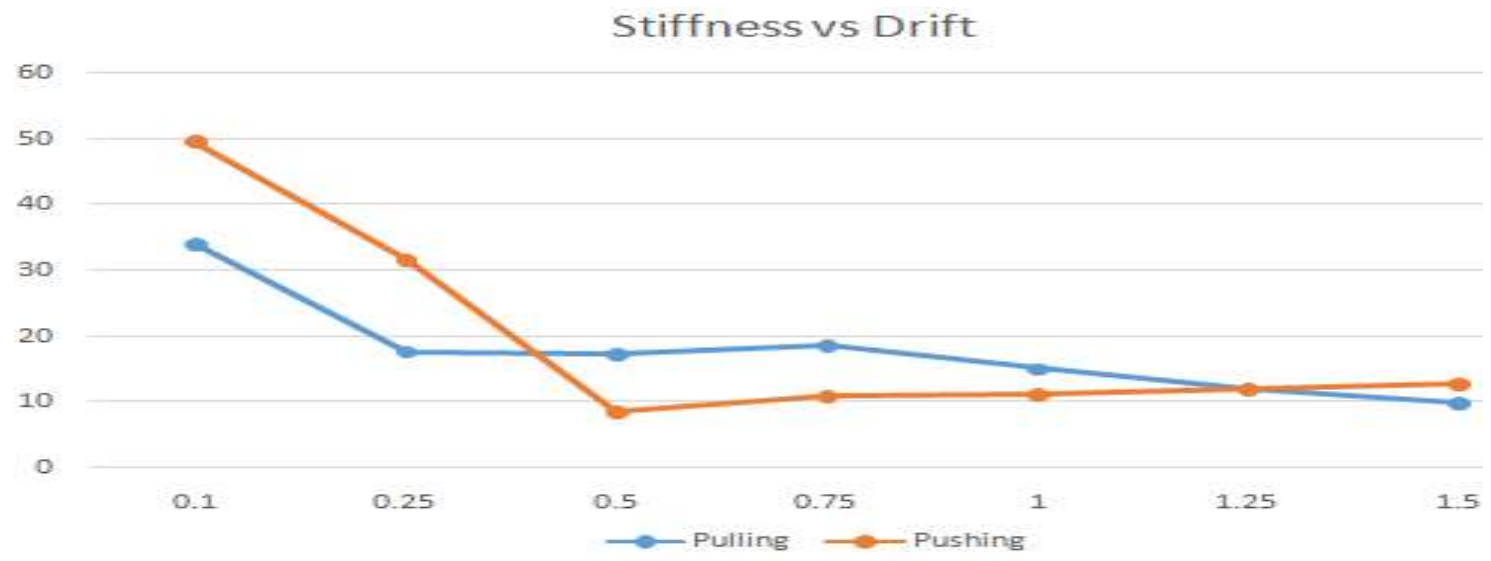

Fig.10. Stiffness profile of wall based on LVDT 3

It was discovered that LVDT 4 as shown in Fig. 11 was showed the similar pattern of stiffness as discussed in LVDT 3.Fig. 12 shows the cracks occurred at wall-slab joint. Spalling of concrete occurred at top part of the joint when the lateral load is applied on top of the wall. Applied lateral cyclic loading on the sample was induced the alternate tension and compression stress at the joints.

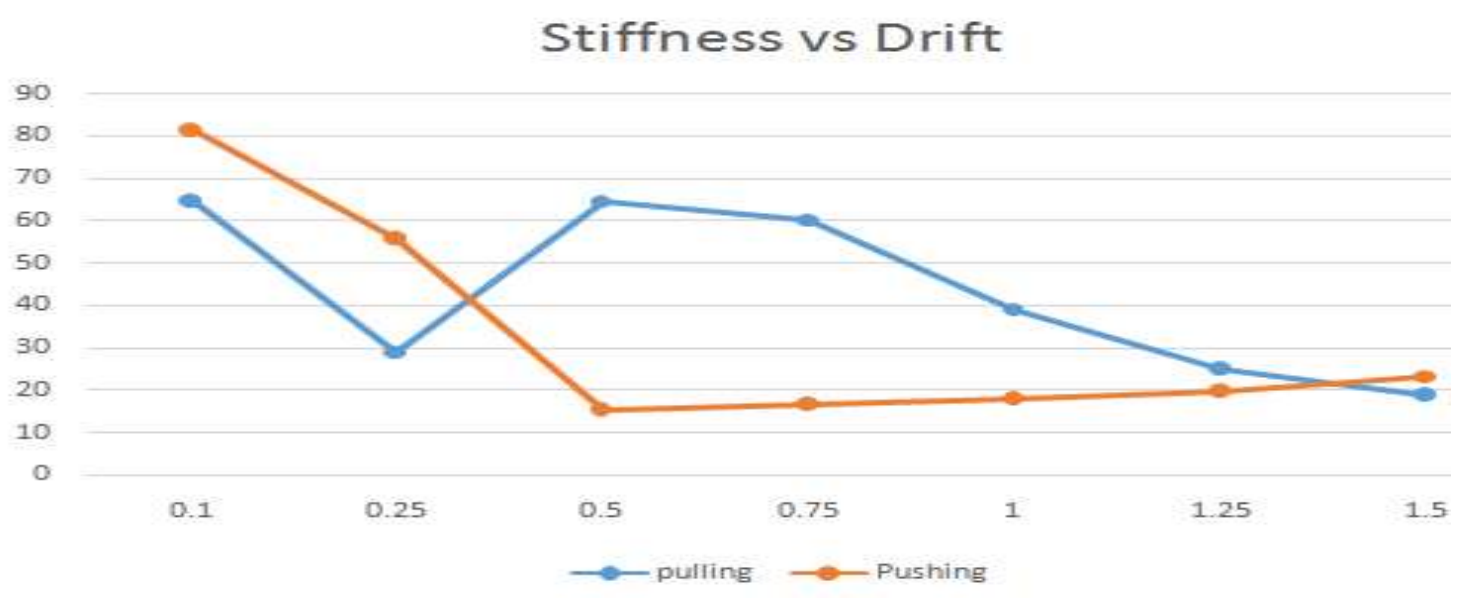

Fig.11.Stiffness profile of wall based on LVDT 4 


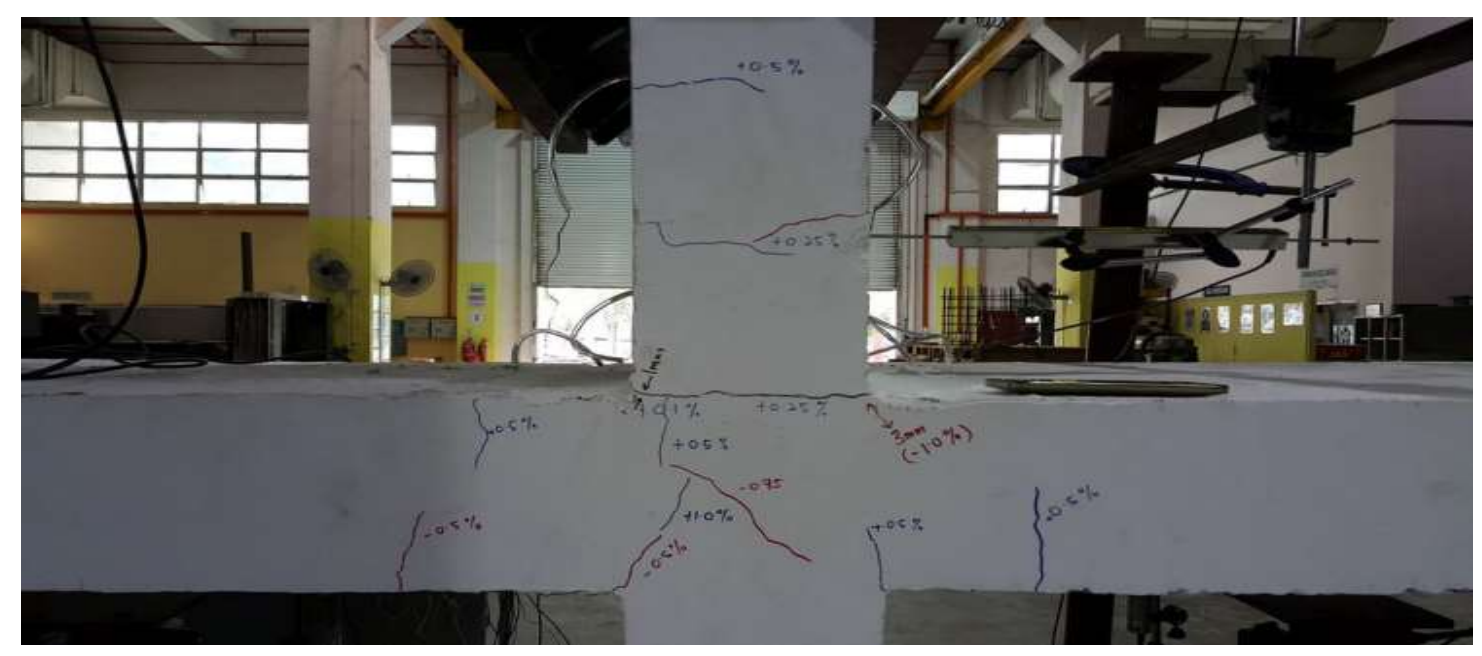

Fig.12. Cracks occurred at wall-slab from side view

Fig. 13 shows the crack on the wall from rear view. It can be observed that the higher stress was induced many cracks at wall which closed to the vicinity of wall-slab joint. Stress in the upper part of wall-slab joint is greater than the bottom part. Therefore, a lot of cracks occurred at upper part of the wall and the cracks started to propagate from slab to both sides of the wall.

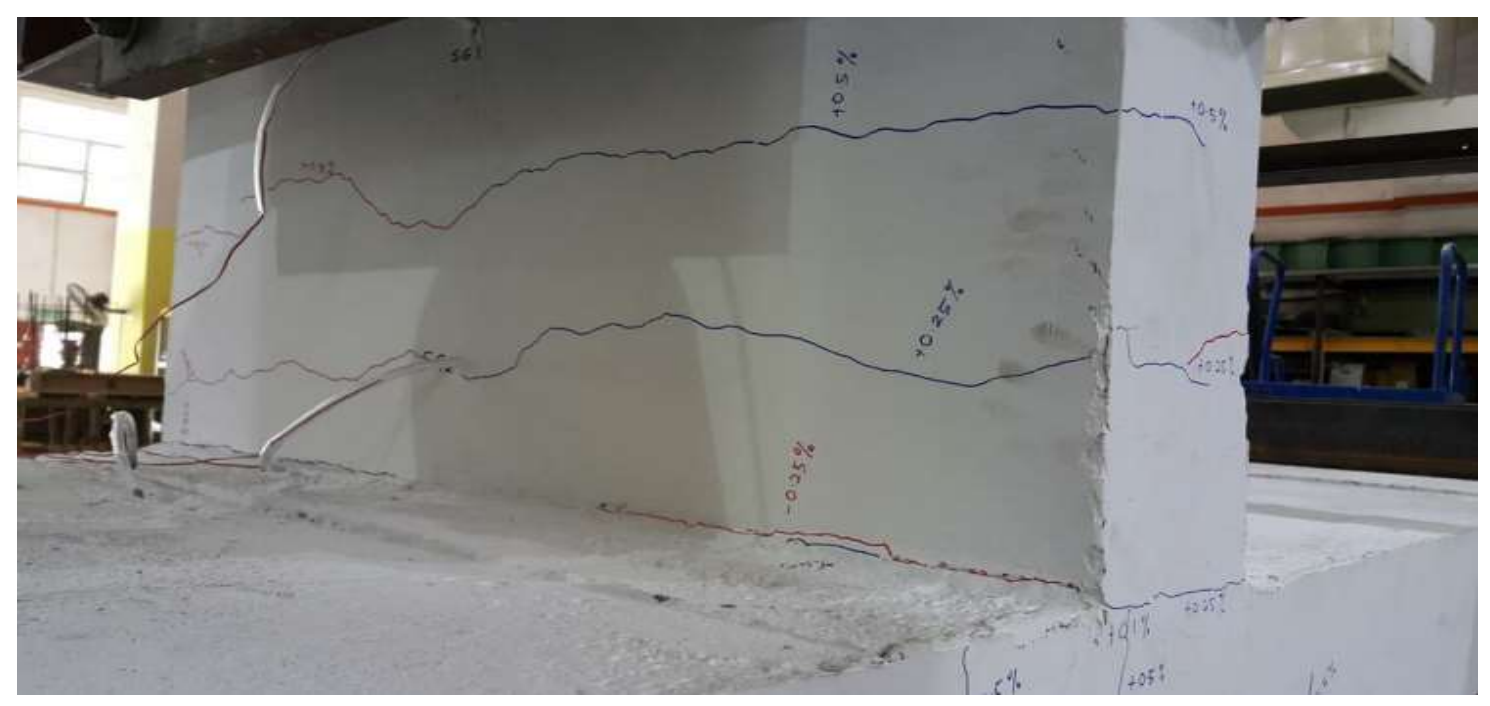

Fig.13. Cracks at wall-slab joint from rear view 


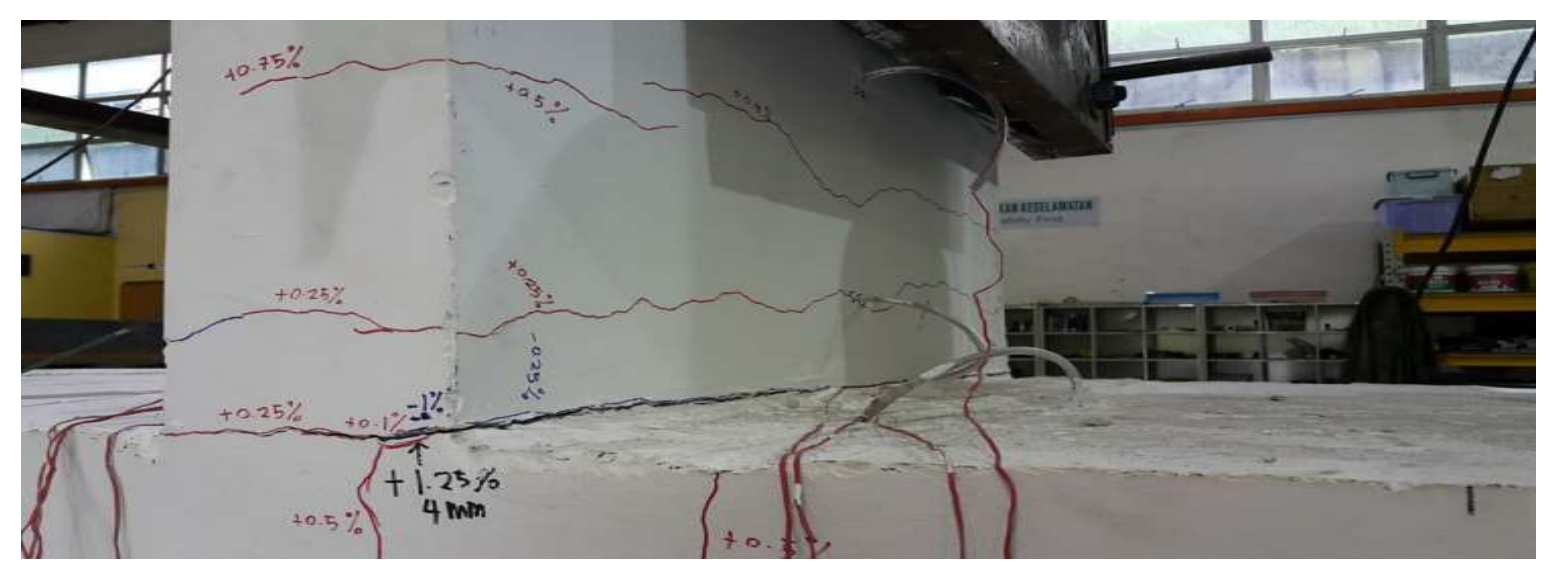

Fig.14. Cracks at wall-slab joint from front view

Fig. 14 shows the crack on the wall from front view. It can be observed that the higher stress was induced many cracks at wall which closed to the vicinity of wall-slab joint at front and the side views of the wall. Stress in the upper part of wall-slab joint is greater than the bottom part. Therefore, a lot of cracks occurred at upper part of the wall and the cracks started to propagate from slab to both sides of the wall and joint as shown in Fig. 15.

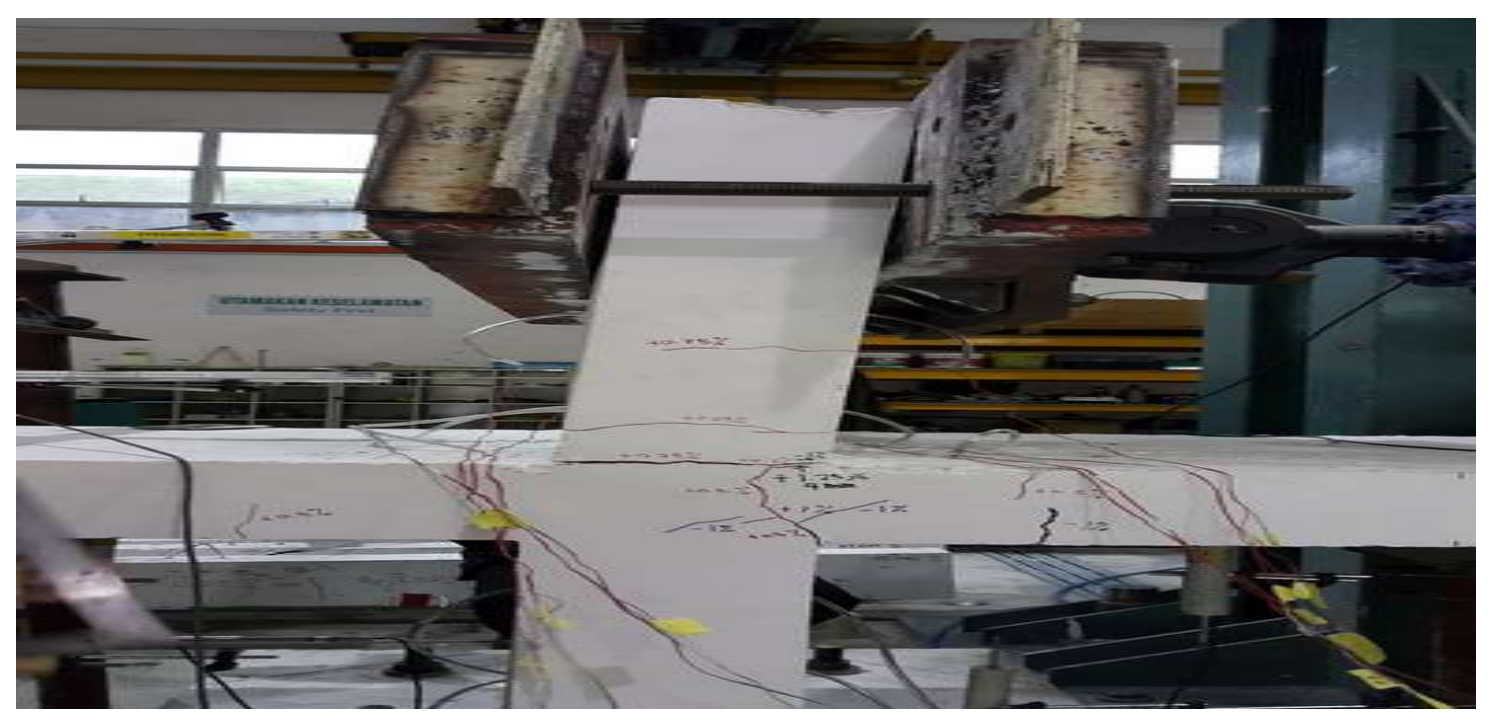

Fig.15. Cracks occurred at wall-slab joint

\section{CONCLUSION}

The biggest hysteresis loops were occurred at LVDT 1 which located the closest to the double actuator. The significant loss of stiffness (resulted from high-energy dissipation) has identified in the early of drift level $(0.1 \%$ t0 $0.5 \%$ drift $)$ and followed by gradual fashion until end of experiment. Therefore, this type of structure needs to increase the percentage of reinforcement 
bars in the concrete and proper detailing at joint is required for seismic loading. Many cracks were observed in the vicinity of the wall-slab joint. Most of the cracks developed at the rear wall, bottom of slab and wall-slab joint surface. It was discovered that the wall-slab joint was governed by brittle modes failure. The minimum amount of vertical and horizontal steel at the wall-slab joint was unable to carry the additional load. Therefore, spalling and cracking of concrete cover were observed, longitudinal reinforcements yielded and fractured suddenly without any warning.

\section{ACKNOWLEDGEMENTS}

The authors would like to thank to Ministry of Education, Malaysia for funding the research project through the fund [Ref. No 600-RMI/RAGS 5/3 (179/2014)] and the Research Management Institute (RMI), UniversitiTeknologi MARA(UiTM)Pulau Pinang for the administrative support. Nevertheless, the authors also want to express their gratitude to the technicians of Heavy Structures Laboratory, Faculty of Civil Engineering, UiTM for conducting this research work successfully.

\section{REFERENCES}

[1] Balkaya C, Kalkan E.Nonlinear seismic response evaluation of tunnel form building structures.Computers and Structures, 2002,81(3):153-165

[2] Yuksel S B, Kalkan E.Behavior of tunnel form buildings underquasi-static cyclic lateral loading. Structural Engineering and Mechanics, 2007, 27(1):99-115

[3] Paulay T., Priestey M. J. N. Seismic design of reinforcement concrete and masonry buildings. New York: John Wiley and Sons, 1992

[4] Gioncu V., Mazzolani F.M. Ductility of seismic resistant steel structures.Florida: CRC Press, 2003

[5] Agarwal P., Shrikhande M. Earthquake resistant design of structures. New Delhi:Prentice-Hall,2007

[6] Booth E., Key D. Earthquake designs practice for buildings.London: Thomas Telford Ltd, 2006 
[7] Otani S. Earthquake resistant design of reinforced concrete buildings. Journal of Advanced Concrete Technology, 2004, 2(1):3-24

[8] Jacobsen L S.Steady forced vibrations as influenced by damping. ASME Transaction,1930,52(1):169-181

[9] Saiful A B M, Jameel M, Jumaat M Z.Seismic isolation in buildings to be a practical reality: Behavior of structure and installation technique.Journal of Engineering and Technology Research, 2011,3(4):99-117

[10] Kaushik S, Dasgupta K.Seismic damage in shear wall-slab junction in RC buildings.Procedia Engineering,2016,144:1332-1339

[11] Yee H M, Choong K K, Rohim R.A background study on plain wall system.International Journal of Engineering and Technology,2013,5(1):54-56

[12] YeeH M, Ismail S I H.An investigation on effect of rebar on structural behaviour for wall-slab system.In IEEE Business Engineering and Industrial Applications Colloquium,2012,pp. 13-32

[13] YeeH M, Ismail S I H.An investigation on bending capacity of support stiffness wall-slab structural system by using single layer and double layer of rebar for residential project. Advanced Materials Research, 2012, 446(449):3670-3673

[14] Yee H M, Choong K K, Rohim R.Experimental study on bending capacity of plain wall system.Applied Mechanics and Materials, 2012, 187:157-160

[15] Abdul H N H, Masrom M A. Seismic performance of wall-slab joints in industrialized building system (IBS) under out-of-plane reversible cyclic loading.International Journal of Engineering and Technology, 2012,4(1):26-33

\section{How to cite this article:}

Masrom M A, Yee H M, Mohamed M E, Hamid N H A. Seismic performance on stiffness and hysteresis loop of interior wall-slab joint for tunnel form building designs to british standard. J. Fundam. Appl. Sci., 2017, 9(5S), 75-87. 